\title{
Pragmatic Errors and Transfer of Foreign Learners of Indonesian: The Case of Refusals
}

\author{
I Made Rai Jaya Widanta \\ Mechanical Engineering Department, Bali State Polytechnic, Kampus Bukit Jimbaran street, Kuta Selatan, Badung- \\ 80364, Bali, Indonesia \\ Putu Dyah Hudiananingsih \\ Accounting Department, Bali State Polytechnic, Kampus Bukit Jimbaran street, Kuta Selatan, Badung-80364, Bali, \\ Indonesia
}

Anak Agung Raka Sitawati

Administration Department, Bali State Polytechnic, Kampus Bukit Jimbaran street, Kuta Selatan, Badung-80364, Bali, Indonesia

I Wayan Dana Ardika

Civil Engineering Department, Bali State Polytechnic, Kampus Bukit Jimbaran street, Kuta Selatan, Badung-80364, Bali, Indonesia

\begin{abstract}
Pragmatic transfer, an emerging part of interlanguage pragmatics (ILP), has been receiving serious attention from applied linguists currently. This study was aimed at investigating pragmatic errors and pragmatic transfer learners made and effect of second language (L2) proficiency to their pragmatic transfer. Eighteen students of Darmasiswa who have been learning Indonesian language and culture form Bali State Polytechnic (PNB) and from Teacher Training Institute of Saraswati Tabanan, Bali, Indonesia were involved as research participants. Discourse completion test (DCT) consisting of nine situations designed with sociocultural aspect of power, distance, and rank of imposition (PDR) was used to elicit data of refusal strategies. The data were analysed to see pragmatic errors, pragmatic transfer, and effect of $L 2$ proficiency on participants' pragmatic transfer. Result of analysis revealed that learners' pragmatic competence was still low. They were pragmalinguistic and sociopragmatic errors made dealing with Indonesian noun phrase (NP) structure, the use of verb, noun, prepositions which are very different from English patterns. Moreover, pragmatic transfer was frequently made due to learners' shortage of L2 pragmatic proficiency and learners' L1 cultural knowledge. In addition, learners' pragmatic transfer was found to be strongly influenced by learners' $L 2$ proficiency.
\end{abstract}

Index Terms—pragmatic transfer, pragmatics, proficiency, Indonesian language learning

\section{INTRODUCTION}

Undeniably, learning Indonesian language, like learning other second language, also requires that learners should be introduced with pragmatics. In order for them to be able to perform speech acts, they have to be ready with two main treasures: knowledge of form and knowledge of social norms. Knowledge of form is included in pragmalinguistics, i.e. the linguistic resources by which speakers can produce functional utterances, and sociopragmatics, i.e. the knowledge about hearers' social rules based on which speakers will be able to produce appropriate utterances (Leech, 1983).

The case which usually comes up on second language acquisition (SLA) is how speakers can produce functionally and socially appropriate speech acts if their knowledge resources of both aspects are still limited, on the other hand, their knowledge of mother tongue still dominates their minds. Consequently, they are only able to realize poorly structured sentences of target language (TL) which adopt some of their L1 sentences or phrase structures or social norms. In this case, transfer of either language or pragmatic will occur. Language transfer is the influence resulted from the similarities and differences between the target language and any other languages that have been previously acquired (Wang, 2015). Language transfer is a common issue in SLA and foreign language teaching. It is also a domain of cross linguistic.

The present study is focused on responding to the following questions:

1. What pragmatic errors did learners make?

2. To what extend were pragmatic transfers performed by learners?

3. Does proficiency affect their pragmatic transfer?

Pragmatic transfer, as a part of language transfer, is a newly emerging area of study known as interlanguage pragmatic (ILP). Its emergence is caused by the effect of similarities and differences between the first language and the 
second language of speakers. To put it deeper, its existence is caused by a number of aspects, such as cultural differences (Connor, 1996); pragmalinguistic and sociopragmatic (Leech, 1983); as well as speakers' first language (L1) background and their second language (L2) proficiency (Hui, 2010). Learners of English as a foreign language (EFL) often attempt to compensate for their lack of knowledge by transferring some features of their L1 to L2. This is triggered by the desire they would like to achieve, i.e. they should be able to convey something even though with the production of functionally and culturally inappropriate sentences (Tavakoli and Salva, 2013). The problem about misuse of language forms functionally and social norms appropriately to produce sentences results in an endeavour of transferring what they have based on their L1 knowledge. Thus, transfer can be drawn as the use of native language knowledge in the acquisition of L2 (Gass and Selinker, 1992), which sometimes may lead to communication breakdown or pragmatic negative transfer (Thomas, 1983). Syahri (2007) underlines that pragmatic transfer, in the context of interlanguage pragmatic transfer occurs due to the culture difference. For instance, Indonesian learners often transfer the non-acceptance strategies using 'No' when responding to English compliment which they usually use in Indonesian language. In line with this notion, Zegarac and Pennington (2000) states that pragmatic transfer exists when there is influence on newly learned L2 knowledge by the existing native language knowledge in mind. It appears when people from different cultures communicate with each other without perceiving their different culture. In this case, miscommunication may probably happen and pragmatic transfer may probably occur $(\mathrm{Bu}, 2011)$.

There have been some studies administered in the field of pragmatic transfer. However, those research utilized different speech acts (SA) or topics to raise, such as 'suggestion' (Bu, 2011), 'request strategies' (Noda, 2013; Hui, 2010; Loutfi, 2016; Syahri \& Kadarisma, 2007; Alam \& Gill, 2016), 'negative transfer' (Wang, 2015), 'refusal strategies' (Tavakoli \& Salva, 2013; Jafari, 2018), and 'effect of L1 pragmatic transfer' (Alhadidi, 2017).

$\mathrm{Bu}$ (2011) investigated pragmatic in suggestion strategies by Chinese who learn English language. The study was also in attempt to see what kind of pragmatic transfer in suggestion strategies occurs in intercultural communication and how the transfer occurs. The study involved thirty participants (ten English native speakers, ten Chinese learners of English, and ten native Chinese speakers). Data of pragmatic transfer in suggestion were obtained by using discourse completion task (DCT). By the help of Chi-square, the collected data were compared to see frequency of the use of suggestion strategies. Finding was successfully drawn that Chinese learner of English tended to use direct suggestion and hedged suggestion more frequently than English native speakers group. The transfer of pragmatic was done from culture of Chinese. The research proposed that, in field of pedagogy, teacher should incorporate materials about crosscultural differences into instruction syllabus for teaching. In addition, in the teaching activities, teachers and materials designers have to expose students with formulae of suggestions which are made as contextual as possible.

Investigation of pragmatic transfer in SA of request was held by Noda (2013). The pragmatic transfer was focused on request written in email. The study was attempted to investigate how American learners of Japanese perform request SA in email. Specifically, it was in purpose to draw differences between request by Japanese native speakers and Japanese learners in terms of explanatory sequence, request strategy, sentence final form. In addition, the study was aimed at searching if there was evidence of L1 pragmatic transfer from English language to Japanese and if social aspects of power (P), distance (D), and rank of imposition (R) affect request realization. DCT with ten situations were applied for participants to make request. Learners' performance was compared to that of native Japanese speakers to see if there were any differences and similarities between the two performances. Data of requests were analysed from point of view of 'explanatory sequence, request strategies, and politeness' and 'sentence final form'. Results of analysis revealed that Japanese learners wrote noticeably fewer explanation sequences than Japanese native speakers. Japanese learners were influenced by $\mathrm{P}$ but Japanese native speakers were not. Japanese learners could produce shorter explanatory sequence than Japanese native speakers in all situations. Negative transfer occurred in the use of direct questions from English. Lastly, Japanese learner could use more limited apology strategy than Japanese native speakers.

Research on request by Hui (2010) was undertaken to examine the hypothesis that 'there are some common and unique pragmatic features in English text'. Explicitly, it was aimed at drawing pragmatic transfer that emerges in English email written by Chinese L2 English speakers. By involving thirteen participants with different English proficiency (based on their IELTS score) and exposure, there were 104 emails successfully analysed. The participants were also given questionnaires to see factors that affect their pragmatic performance. The result of analysis indicates that level of proficiency did not affect their pragmatic performance. The extent of pragmatic transfer of each individual participant was complex, triggered by some aspects, such as English proficiency, exposure to English, and confidence in using the language. Most participants, when making request SA, were found to be direct on the sentence level but indirect on the level of discourse.

Loutfi (2016) tried to explore Moroccan EFL learners produced request in order to investigate if L2 pragmatic competence acquisition is still desired. The research was aimed at comparing the average frequency of direct and indirect strategies used by native Moroccan English learners and native English speakers. In line with the Hui's (2010) study, this research was also undertaken to see if proficiency gives impact to transfer they made. The study raised up a hypothesis, i.e. 'transfer decreases as the study level increased'. The subject involved was 60 people (40 Moroccan learner of English and 20 native Speakers of English). Request strategies were set using frame work of CCSARP (Blum-Kulka, 1991). Data was collected using DCT with 7 situations with focused on investigating transfer of pragmalinguistics and sociopragmatics. Upon data analysis, some conclusions were found that Moroccan learners of 
English were not satisfactory. Sociocultural dimensions were fundamental to support acquisition of L2. There was transfer from L1 to L2 done by Moroccan learners of English. And, pragmatic competence was found to play a major role in the communicative failure of Moroccan learners of English. The result was emerging some pedagogical implications, such as teacher should include teaching pragmatic competence in curriculum to raise students' pragmalinguistic and sociopragmatic awareness of target language. Thus, teacher should be equipped with knowledge of pragmatic variation, how to teach pragmatic in L2 and how to asses it. In addition, students should be exposed to authentic L2 materials.

Apart from Loutfi's (2016) work, Syahri \& Kadarisma (2007) investigated pragmatic transfer in request realisation by 68 Indonesian university students majoring in English study. The research was focused on recognizing how pragmatic transfer occurred in SA of request in EFL learners and to present enactment of language learners' SA which specify one type of SA realization. The participants pursuing 450 TOEFL score were involved in the project and provided with DCT questionnaire including 15 situations using variable of Power (P) and Distance (D). Result revealed that external modification was appearing more frequently than internal modification. Indonesian learners of English are considered to be influenced by their native culture norms. The research participants were also found to be able to embed some supportive move prior to executing head acts, and inserted move in initials position. However, the study did not figure out pedagogical implication to be proposed for instructional needs.

Alam \& Gill (2016) also did a work on request and apology done by two groups of speaker, Pashto English learners and Siraiki English learners. The study was focused on investigating effectiveness of pragmatic transfer of both speakers from L1 to L2, their accomplishment of SA of apology and request in target language, as well as what specific culture and linguistic resources are transferred, why they use pragmatic transfer and how it affects pragmatic competence. DCT and semi structured interview were applied to 8 participants of both speakers who were from English cultural and linguistic background. Result of the discussion revealed that both speakers showed different performance. Pashto English speakers were more pragmatic and indirect in realizing request SA and were more direct in apology SA. Meanwhile, English speakers of Siraiki were more indirect and polite during their accomplishment of both SA.

Existence of pragmatic transfer was also proved by the work of Wang (2015) which investigated negative transfer in English writing, number of attributive clauses errors commonly occurred in Chinese students' writing and influences interferences made to the learners writings. It involved 60 students of Juinjiang University who were majoring in English and were given 30 minutes to do online writing composition. Data of research was also obtained from an interview. The collected data were sorted out to see frequency of mistakes. The analysis was also done to see interference in English writing, in terms of how many errors were made, how interferences influenced Chinese students writing. Result of analysis indicated that there were five error categories, including avoidance strategies, redundant pronoun, and omission of preposition, underused, misplaced and redundant relative words. It was also found that transfer error occurred in students' writing as they consciously or unconsciously turned to their L1 and they translate every words, i.e. English words with Chinese meaning. Suggestion to find more valid data was given by improving the study limitation, use of more than university as locus, combine written version with oral test, and use of formal and informal situation.

Research in refusals SA was also carried out by Tavakoli \& Salva (2013) and Jafari (2018). Tavakoli \& Salva (2013) investigated backward pragmatic transfer. This study used DCT to collect data and involved 44 Persian speakers (24 of whom were Persian EFL leaners, 20 of whom were native speakers of Persian. Persian EFL learners were grouped into three levels of elementary, intermediate and advanced using Oxford Placement Test (OPT). Data were collected via 3 scenario role plays. Analysis was in purpose to examine participants' multiple competence by investigating backward pragmatic transfer from English to Persian when performing refusal to invitation. In addition, the study was also undertaken to explore participants' frequency and content of refusals strategies in L1 regarding the social status of $\mathrm{P}$ and D and proficiency level of EFL learners. Result of analysis fostered that there was a significant difference between Persian native speakers and high proficient EFL learners in terms of content and frequency of refusal strategies. EFL learners seemed more direct and employed more specific response to their refusal than Persian native speakers. However, Jafari's (2018) work was focused on investigating pragmatic transfer on Iranian EFL learners' refusal strategies and finding out their pragmatic competence. In that study, 60 EFL Iranian learners of advanced level aged 2031 were involved. Multiple choices DCT was applied to collect data on realization of pragmatic recognition ability of participant while written DCT was applied to 20 participants of advanced learners of English. MDCT was built up of 10 situations in English. Result of study revealed that L1 interference caused 50\% failure of Iranian EFL elementary learners. Intermediate and advanced learners mostly had difficulty in pragmatic recognition of English language. It can be implied that pedagogical intervention shall introduce pragmatic and culture aspects.

On different ground, Alhadidi (2017) researched the effect of L1 pragmatic transfer on the acquisition by Saudi speakers of English. 42 participants of Saudi speakers of English were involved and multiple choices questionnaire was employed to examine participants' pragmatic awareness of various SA. Specifically, it was undertaken to see if Saudi English speakers relay on their L1 pragmatics when they communicate in English, and do the beginner and advanced speakers transfer pragmatics from L1 to L2 equally. Data were collected by using online survey through Google forms. Data were analysed by using SPSS particularly that of paired sample t-test to compare result of T1 and T2. T test statistical significant was also used to draw differences between the averages of the two groups. Result of analysis 
showed that beginner level of EFL learners tend to rely on L1 due to shortage of L2 pragmatic knowledge. During process of SLA they actively transfer knowledge of their native language to generate their L2 acquisition process. In contrast, advanced group did not show L1 pragmatic during the acquisition meaning that the higher the level of proficiency, the less L1 pragmatic is transferred.

\section{METHOD}

This study involved eighteen foreign learners of Indonesian who had been learning Indonesian language intensively for one year in Bali. It is a scholarship program financed by government of Indonesia for foreigners who learn Indonesia language and culture in universities or the like all over Indonesia. The research participants involved are from numerous countries aged between 20 - 35 years old. They also have different level of Indonesian language (L2) proficiency upon given a placement test. The study was undertaken in the Darmasiswa classes at Bali State Polytechnic and Teacher Training Institute of Saraswati Tabanan, Bali, Indonesia.

In its implementation, the participants were given placement test to see at what level of proficiency they were. The test was taken from the regular test provided by Darmasiswa program which is usually used to measure students' proficiency prior to their level determination. The test was a-multiple choice test consisting of 40 questions. The result of test was listed to recognize participants' base- line. To collect data of participants' pragmatic competence particularly pragmatic transfer, participants were given DCT consisting of role play of invitation to elicit their performance of refusal SA. DCT consists of nine situations of request which included social aspects of power (P) and distance (D) of the hearer. Participants of research were to make refusal to request in each role play card. Upon the pre-test, participants were given a treatment in the form learning Indonesian language (particularly grammar) using self-directed learning (SDL) model. The model was developed in previous research. However, this research was not focused on measuring effectiveness of SDL specially designed for Indonesian language learning, but on learners' pragmatic errors and transfer made. Upon one session of learning of Indonesian language, they were given post-test. These tests were given to recognize whether learners' proficiency of L2 was in line with transfer they made. Their responses in form of refusal SA were noted on spaces next to each request or invitation. Although they were requested to make refusals in Indonesian language, some of them made it in English as they were not able to perform their capability. All of their works were collected and explicated. Participants' answers were listed and codified. Their responses were then analysed using theory of transfer.

\section{RESUlT AND DiSCUSSION}

Data analysis on participants' refusal performance led in some findings regarding pragmatic competence of participants. As described above, there are two main aspects viewed concerning the data, they are 'pragmalinguistic' and 'sociopragmatic'. Pragmalinguistic errors deal with the use of linguistic resources or form functionally, such as grammar, structure, collocation, phrases patterns, use of possessive pronouns, and things dealing with forms. Sociopragmatic errors deal with use of form in relation to correct context.

\section{A. Pragmalinguistic Errors and Transfer}

In situation 1, pragmalinguistic errors are drawn as follows. The use of 'anda pergi' which is based on the interview result means 'you may go' which refers to a giving permission. The utterances '...tetapi anda akan bekerja satu hari lagi' is not appropriately used to tell necessity as akan is used to tell futurity. Thus, harus referring to 'have to' is appropriate word instead. And the expression 'Kamu bekerja untuk hari ini..., is also less appropriate functionally as it is suitably used for telling necessity, and it requires 'harus' to be 'kamu harus bekerja untuk hari ini.

Responses to situation 2 of the role play card were not also proper. The utterance 'semua yang terbaik untuk ujian' has not been in line with the speaker intention to say 'let's do the best for our exam'. Additionally, 'the expression 'setelah ujian itu, tolong datang ke kelas' is still not relevant to what the speaker meant by "after the exam, please come to the class'. The article 'the' is translated as it is really needed in English language. The utterance '...hari examnya saya belajar juga, tidak ada mungkin', includes two errors. First, native Indonesian will commonly express 'pada saat ujian (exam)' and 'tidak mungkin saya meminjamkan buku itu kepada anda' which needs to have a complement after the word 'mungkin'.

Dealing with situation 3, 'ya pak, sebentar, saya punya istirahat untuk makan siang sekarang' is less proper as native speakers of Indonesian commonly say 'beristirahat' to refer to 'I'll have a rest'. Apart from this, 'saya mau mengantar anda di sana' also used improperly. Its problem is on use of preposition $d i$ which shall be replace with $k e$ to express a movement instead of existence.

Two expressions in situation 4 may be based on or derived from English expressions thus sound less appropriate. '....aku mau pergi dengan kamu, aku akan senang' is not considered common in Indonesian since sincere expressing marker is commonly inserted in sentence or clause, commonly placed between subject and verb, as 'saya sangat senang bisa ikut dengan kamu'. And expression 'Oh tidak, saya sakit dan tidak bisa pergi ke konser' may be derived from the speaker's L1 pattern so that it sounds very expressive. As it is in purpose to apologize, it may be more appropriate to express 'Maaf, saya sakit dan tidak bisa pergi ke konser'. 
Two expressions in situation 5 also seemed to be awkward. 'Terima kasih pak untuk invitasi, saya akan coba, saya mau ke "kesantunan berbahasa" pada seminar minggu depan di kampus'. By expressing the utterance, the speaker seemed to lack of verb treasure to express the verb 'invitation' in Indonesian language which should appropriately be 'undangan'. The speaker's confusion in arranging sentence, i.e. which part of sentence shall be placed as an adverb of place following a verb or as a complement placed at the end of the entire sentence made his/her expression sounds confusing. The preposition $\underline{k e}$ must always be followed by a place or event and the name of event is usually placed after the event.

In situation 6, some expressions failed to express clear meaning to hearer as they contain disagreement between subject, verbs, and complement. In utterance 'Terima kasih untuk mengundang, saya akan kehadiran', the words terima kasih shall be followed by utterance 'karena telah mengundang saya or atas undangannya'. In addition, the modal verb 'akan' (will) shall be followed by verb 'hadir' to make an acceptable sentence. The other case, 'saya akan hadir pada kehadiran anda' also expose a puzzling information as it loses a proper part of speech. The sentence needs a noun expressing an event, or the bold word needs to be formed into a noun as it is preceded with preposition 'pada' (on). Thus, the following word which suits to fill in the position is any word expressing an event, such as 'pesta' (party), 'rapat' (meeting), and so forth.

In situation 7, the utterance 'tidak apa-apa, kami adalah teman' fosters an error of form, as 'kami' is used when hearer is not included in an action. However, this case or context needs that the hearer is included as the doers, thus it has to use 'kita' instead. The imperative sentence 'Tetapi mengemudi dengan aman' sounds awkward as it misses the use of appropriate verb form. The used verb functions as declarative verb which does not mean to give a direction to hearer. Thus, the sentence should use 'mengemudilah' or 'tolong mengemudi' to make an imperative sentence. Utterance 'Saya bukan marah karena situasi itu' also shows less appropriateness as bukan is used incorrectly and karena situasi itu sounds uncommon. The word bukan is not appropriately used to precede an adjective, thus it should use tidak instead, and situasi itu is not commonly used to refer to an event or incident. To make it more functional, the sentence should sound 'Saya tidak marah karena kejadian itu'. The utterance 'Tapi hati-hati untuk sepeda motor' does not also sound properly as it is not commonly uttered, even though in less formal verity. In order to make it proper, the sentence should sound 'Tapi hati-hati dengan sepeda motornya' or 'Tapi hati-hati naik sepeda motor'. Lastly, 'Tidak apa-apa, saya bisa menggantinya itu' is less relevant grammatically as it uses double object pronouns '-nya' and 'itu'. The sentence should use only one of the two object pronouns to avoid ambiguity so that it can foster a clear intention.

Responses to situation 8 also foster a number of errors functionally. The utterance 'Terima kasih untuk baru' to response to speaker's promise to change the hearer's torn book with a new one still consists of incorrect use of word 'untuk'. The sentence should sound 'Terima kasih karena anda telah mengganti buku tersebut dengan yang baru'. The utterance, 'Anda tidak harus akan menggantinya dengan yang baru' in addition, also contains abuse of words harus and akan which are commonly used in English. However, the two words do not normally emerge mutually in a sentence. In order to make it more appropriate 'akan' can be omitted that the sentence will function to express negative necessity. The sentence 'Tidak apa-apa bro, tetapi aku mau baru buku minggu depan' indicates a mistake of noun phrase (NP) structure. The Indonesian NP structure should be N-Modifier, thus it will form 'buku baru'. Lastly, utterance 'Tidak apa-apa temanku, itu tersebut robek di anda' according to further discussion concerning what the speaker meant by writing such sentence should sound 'Tidak apa-apa temanku, buku tersebut sudah robek sebelumnya'.

Situation 9 also exposes a number of abused forms or sentences. They are 'Terima kasih untuk dipromosikan chef, maaf tetapi saya tidak bisa memberi waktu', 'Mohon maaf bapak, saya tidak bisa karena ada situasi keluarga', 'Maaf pak, saya tidak bisa promosi karena keluarga saya memerlukan. Mungkin setelah tiga bulan saya bisa berpromosi, terima kasih', 'Maaf boss, saya sibuk untuk keluarga saya', 'Istrinya tidak ada waktu untuk anak-anaknya, jadi saya mau tinggal pada anak-anak anda untuk waktu kecil'. The use of phrase untuk dipromosikan chef sounds awkward. The word 'terima kasih' requires a clause 'karena saya sudah dipromosikan menjadi chef, to make proper sentence. The phrase 'ada situasi keluarga' to express a reason, also needs to be revised to be ada urusan keluarga. The clause 'tidak bisa promosi' should be made as a passive clause to make an accepted sentence, therefore it should be 'tidak bisa dipromosikan'. In addition, the clause 'saya sibuk untuk keluarga saya' should be 'saya sibuk karena urusan keluarga'. The use of possessive adjective -nya is inappropriate which should be using -saya as the speaker wants to express his or her family, therefore it should be 'Iastri saya tidak ada waktu untuk anak-anak saya'. And at last, 'jadi saya mau tinggal dengan anak-anak anda untuk waktu kecil' should be 'jadi saya mau tinggal dengan anak-anak saya untuk sementara waktu'.

Pragma-linguistically, speakers' performance on refusal SA above exposed evidence of pragmatic transfer. It is obviously recognized that speakers' production relies very much on their L1, in this case English language. The case of transfer can be explained as follows.

The clause 'setelah ujian itu' in the sentence 'tidak apa-apa, setelah ujian itu tolong datang ke kelas' was formed based on speaker's L1 knowledge 'after the exam' and is not very common in Indonesian. The clause should be 'setelah ujian' to make it sounds more appropriate. The other sentences containing transfer from L1 to L2 can be seen on the sentence '...hari examnya saya belajar juga, Maaf, maaf tidak ada mungkin'. Transfer of L1 (English language) is clearly viewed here that hari examnya was derived from English pattern 'on the exam day' which in Indonesian sounds 
awkward. 'Tidak ada mungkin' was also derived from the form 'there is no possibility' which should be expressed 'tidak memungkinkan' or 'tidak ada kemungkinan'.

The clause 'saya punya istirahat' and 'saya akan mengantar anda di sana' also indicate that L1 still dominate speakers' mind. To express 'I will have a rest' is very common in their L1, however it should certainly be converted into Indonesian clause 'saya mau beristirahat'. In addition, adverb of place 'there' was figured out to be 'di sana' which should be ' $k$ e sana'. A part from these examples, utterances 'Ya saya terima bro. Aku mau pergi dengan kamu. Aku akan senang' indicated that speaker converted it from the English utterance 'I'd like to', which, common Indonesian expression should merely say 'saya senang bisa ikut'.

'Terima kasih untuk undangan' shows a transfer. It is very common in speaker's L1 to embody the preposition 'for' in 'Thank you for the invitation'. However, grammatical Indonesian sentence should be 'Terima kasih atas undangannya'.

Using phrases, for instance noun phrase (NP) usually confuses the participants. Their L1 knowledge which formulizes NP with Adjective - Noun or Modifier - Noun triggers the speaker to produce sentence 'Saya mau ke 'Kesantunan berbahasa' pada seminar minggu depan di kampus'. Another example is the use of 'baru buku' which should be 'buku baru'. The speaker did not seem to recognize that Indonesian NP construction is formulized with N Adjective / Modifier.

The case of part of speech also puzzles the speakers. They failed to comprehend and determine which is noun and verb. The utterance 'saya akan kehadiran' was formed because of speaker's belief that kehadiran is a verb.

\section{B. Sociopragmatic Errors and Transfer}

Sociopragmatic error seemed to occur less frequently than pragmalingusitic error. However, it was still significant to indicate that speakers were less competent. The case was triggered by speakers' insufficient knowledge of aspect of social status, i.e. power (P) and distance (D).

The utterance 'Kapan anda mau berbelanja ke supermarket? Katakan padaku' contains inappropriate use of 'anda' and 'padaku' as the hearer whom the speaker talked with was his or her superior at work who has $+\mathrm{P}$ and $+\mathrm{D}$. At office or workplace context, communicating with superior requires polite and formal words and expression. The Indonesia utterances utilized seemed that the speaker speaks to his or her workmate who have the same power or no distance with him or her.

Another utterance 'Ya pak, sebentar. Sepuluh menit dan saya bisa mengantar anda ke supermarket' contains sociopragmatic errors as it is violating the principle of politeness. On the basis of Indonesian culture, communicating with someone who is superior at work requires the speaker to be obedient to the principle. Although addressing system with 'pak' (sir) was considered honorific, but the use of subject 'anda' is not polite when addressing such an interlocutor, as he or she has higher power $(+\mathrm{P})$ and there is distance between them $(+\mathrm{D})$. In line with this case, speaker's utterance 'Ya terima kasih untuk undangannya. Saya akan hadir pada seminar tersebut' expressed to his or her lecturer, also indicates that the speaker still has insufficient knowledge of sosiopragmatic. Although it sounds nice and shows correct grammatical items, the utterance is still considered less appropriate socially as it omits addressing system 'Pak', an addressing term which has high sense of respectfulness in this context.

In contrast, inappropriate utterance also occurs in the following sentence, where speaker of the utterance should use colloquial sentence as the hearer has lower social status (-P and-D). The utterance 'Tidak apa-apa, kami adalah teman' is not appropriately used by the speaker to his or her staff at office context. This utterance violates politeness principle in Indonesian culture. The expression 'kami adalah teman' indicates that the speaker and the hearer have close relation. However, the fact indicates that both speech participants do not have close relation.

Lastly, the utterance 'Terima kasih untuk dipromosikan chef' and 'Maaf boss, saya sibuk untuk keluarga saya' also fail to position the speaker as someone who respects his or her superior. The utterance should use some markers to show that he or she shows a respect, for instance by saying 'Terima kasih Pak, saya sudah dipromosikan menjadi Chef' or 'Terima kasih, karena Bapak telah memberikan kesempatan kepada saya menjadi Chef'. The second utterance also sounds odd, as the speaker used term of address 'Boss' to speak with his or her superior in a formal situation. In other words, the speaker should embed term of address 'Pak' (sir), and avoid the use of 'boss' and use 'Pak' or 'Bapak' instead.

There are some transfers the speaker made seeing from view point of sociopragmatic. The transfers are fully influenced by the knowledge of speakers' L1 which are contradictive to L2 pragmatic knowledge. There is cultural difference on how to address someone at different context ( $\mathrm{cf} \mathrm{Bu}, 2011$ ). For instance, in $\mathrm{L} 1$ context, it is common to mention name and to use term of address 'boss' or pronoun 'you' but in Indonesian culture, 'you' referring to ' $k a m u$ ' or 'anda' is not commonly used to address someone who is 'superior' at work.

The fact of participants' production can clearly give an indication that they are considered to be less competent pragmatically (pragmalinguistically and socipragmatically). It can obviously be seen from their responses of the nine situations given that they are still a lot of errors on forms they produced. They were able to produce forms, such as noun phrases, clauses, sentences of Indonesian language but they were constructed inappropriately. There were a number of difficulties the speakers faced, such as constructing NP order, using possessive adjectives, using modal verbs, using subject and object pronoun. Most of research participants could produce relatively short answer. They were also formed 
monotonous sentence patterns. This is caused by the fact that grammar still plays an important role for and they have insufficient L2 knowledge.

The fact clearly assures us that in order for them to be able to create good utterances, they have to be proficient at Indonesian language as the target language. Even though, in general some findings of work on pragmatic transfer and pragmatic competence concluded that level of L2 proficiency do not affect learners' L2 pragmatic competence particularly pragmatic transfer (Hui, 2010) and grammatical competence cannot predict speakers' pragmatic competence (Sajaya, 2017), this study emerged a contradictive result. It can be concluded that proficiency level can determine speakers' performance of L2 (Alhadidi, 2017) and transfer of pragmatic from L1 to L2 will decrease if study level of Learners' L2 increases, or the higher is their L2 proficiency level, the more competent they are at performing L2 sentences (Loutfi, 2016).

\section{CONCLUSION}

The study successfully concluded that participants were not considered to be competent pragmatically as they produced pragmalinguistic and sociopragmatic errors. A lot of pragmalinguistic errors were triggered by misconception of using phrase, clause or sentence patterns which made on the basis of their L1. The pattern of NP was mostly made in their L1 comprising Adjective - Noun which, in Indonaesian language, it should be formed Noun - Adjective. The use of verbs and nouns in sentences was frequently switched so that they sound awkward. In addition, prepositions, adverb of places, and specific verb 'have' were used pursuant to English pattern. Apart from this error, sociopragmatic errors were also found frequently. The participants frequently referred to their L1 system which generalize interlocutor with same personal pronoun. The use of 'Anda' was always done to refer to interlocutor who has higher power $(+\mathrm{P})$ and far distance (+D), such as inferior at work or teacher at school. It should be embodied and varied with 'Anda', 'Tuan', 'Bapak or Ibu' and other. "Maaf bos" also sounds awkward when it was used to respond to the owner of a work place or the employer. Thus, "maaf Tuan, Nyonya", "maaf Bapak or Ibu” should be used instead.

Transfer of pragmatic was mostly undertaken as participants were influenced by and relied on their L1 (cf. Bu, 2011; Wang, 2015) and this was done mostly by participants with lower competence than higher competence (Alhadidi, 2017). This was done as their shortage of L2 pragmatic knowledge. The transfers were mostly done as a result of participants' less competence of L2 pragmatic knowledge. The findings were supportive to that of Alhadidi's (2017) and Loutfi's (2016) that transfer of pragmatic is caused by a condition where participants' L2 knowledge is not sufficient and when their study level of L2 decreases. The notions converse that of Hui's (2010) and Sanjaya's (2017).

Further studies are required to be undertaken considering the fact that this study still has some weaknesses. First, number of participants involved was relatively limited. Bigger number of participant need to be involved to find more varied data for analysis. Second, more than one speech acts should be involved to see representative data. In order to find more natural data of speech acts, oral role play card need to be utilized apart from DCT.

\section{REFERENCES}

[1] Alam, M. F., Gill, Aneela. (2016). Pragmatic Transfer: An Interlanguage Study of Pashto and Siraiki English Language Learners. Gomal University Journal of Research, Special Issue III, December, 2016, ISSN: 1019-8180. pp. 143-151.

[2] Alhadidi, Amal Hamdan. (2017). Investigating the Effect of L1 Pragmatic Transfer on the Acquisition of English Language by Saudi Speakers. International Journal of Linguistics ISSN 1948-5425 2017, Vol. 9, No. 4. pp. 63-77

[3] Bu, Jiemin. (2011). A Study of Pragmatic Transfer in Suggestion Strategies by Chinese Learners of English Studies in Literature and Language Vol. 3, No. 2, 2011 p. 28-36 DOI:10.3968/j.sll.1923156320110302.325 ISSN 1923-1 www.cscanada.net www.cscanada.org.

[4] Connor, U. (1996). Contrastive Rhetoric. Cross-cultural Aspects of Second-language Writing. Cambridge: Cambridge University Press.

[5] Gass, S., \& Selinker, L. (Eds.). (1992). Language Transfer in Language Learning. Philadelphia: John Benjamins.

[6] Hui, Shi. (2010). Pragmatic Transfer in English Emails Produced by Chinese L2 English speakers: A Study of the Underlying Cultural Ethos, and the Effect of Speakers' English Proficiency and Exposure to English. A Master Thesis. 2010. Stockholms Universitet.

[7] Indawan, Syahri and Kadarisma, A, Efendi. (2007). Universitas Negeri Malang TEFLIN Journal, Volume 18, Number 2, August. PP. 123-147.

[8] Jafari, Fatemeh \& Hossein Sadeghoghlo. (2018). Pragmatic Transfer of Iranian EFL Learners: The case of Refusals Journal of Applied Linguistics and Language Research Volume 5, Issue 2, 2018, pp. 32-40 Available online at www.jallr.com ISSN: 2376-760X. 2018.

[9] Loutfi, Ayou. (2016). Pragmatic Transfer in Moroccan EFL Learners' Requests 1.Asian Journal of Education and e-Learning (ISSN: 2321 - 2454) Volume 04 -Issue 01, February 2016. Asian Online Journals (www.ajouronline.com) 2016, pp.15-24.

[10] Leech, G. (1983). Principles of pragmatics. London: Longman. Google Scholar.

[11] Noda, Takako. (2013). Pragmatic Transfer in Japanese Requests in Emails Purdue University, takako_125_coco@hotmail.com. Master thesis. West Lafayette. Indiana, pp.1-93.

[12] Sanjaya, Nyoman Suka. (2017). The Effect of grammatical accuracy and gender on interlanguage request strategy. TEFLIN Journal Vol.28, Number 2, July 201, pp.212-235.

[13] Tavakoli, M., Shirinbakhsh, S. (2013). Backward Pragmatic Transfer: The Case of Refusals in Persian. International Journal of Society, Culture \& Language, 2(1), 2014 ISSN 2329-2210., pp. 1-24. 
[14] Thomas, J. (1983). “Cross-Culture Pragmatic Failure. Applied Linguistics. 4:2, 91-112.

[15] Wang, Yifei. (2015). Negative Transfer of Mother Language in English Compositions by Jiujiang University Students. Article available at http://www.shs-conferences.org or http://dx.doi.org/10.1051/shsconf/20151401008.

[16] Zegarac, V, \& Pennington, M. C. (2000). Pragmatic Transfer in Intercultural Communication. In H. Spencer-Oatey(Ed.), Cultural Speaking: Managing Rapport through Talk Across Cultures, 165-190. New York: Continuum.

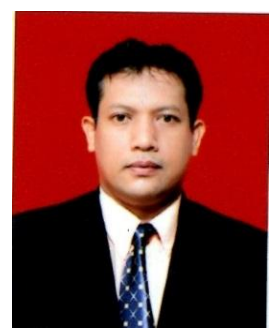

I Made Rai Jaya Widanta was born in Badung, Bali, Indonesia on $27^{\text {th }}$ October 1973. He is a permanent lecturer of English at Mechanical Engineering Department, Bali State Polytechnic, Bali, Indonesia. He pursued bachelor degree (Sarjana Sastra or S.S.) in English literature at Warmadewa University in 1997. He completed his master program and pursued a degree of Magister Humaniora (M.Hum.) in linguistics in 2002 and doctorate program with Doktor (Dr.) degree in linguistics in 2017.

He has been teaching in both private and state universities as well as governmental and private companies. He has been teaching General English and English for Specific Purposes. In addition, he has also been administering English proficiency test, such as TOEFL, TOEIC, English Competence Test, and Proficiency Test of English. His research interests are developing learning model, first and second language acquisition, and interlanguage pragmatics.

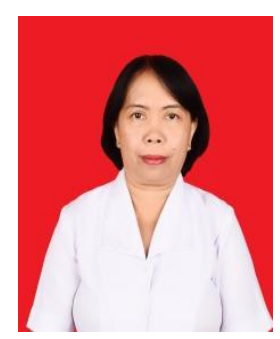

Putu Dyah Hudiananingsih, was born in Malang, East Java, Indonesia on $20^{\text {th }}$ march 1963 . She pursued a bachelor in English in 1988 from Udayanan University and finished her post graduate program in Linguistic in 2007 from the same university.

Her permanent job is a lecturer at Bali State Polytechnic since 1988. She has been assigned to teach General English and English for Special Purposes at Bali State Polytechnic. In addition, she has been teaching English in some colleges and private institution.

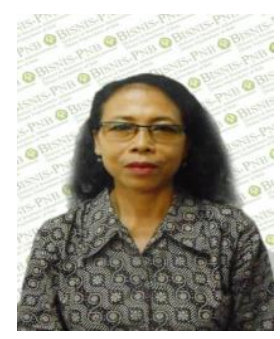

Anak Agung Raka Sitawati was born in Badung on 12August 1961. She pursued her bachelor degree in English literature and was awarded degree of Doktoranda (Dra.) in Udayanan University in 1987. She continued her study to master program in education to Ganesha University of Education and pursued her degree of Magister Pendidikan (M.Pd) in 2010. She works for Bali State Polytechnic and has been teaching both General English and English for Business for about 29 years.

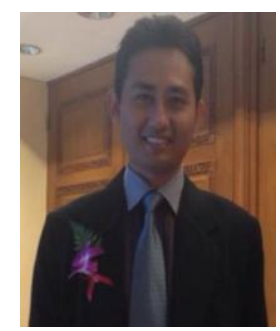

I Wayan Dana Ardika was born in Tabanan on 24 October 1984. He completed his bachelor program in English literature in Warmadewa University and was awarded Sarjana Sastra (S.S.) degree in 2006. He pursued his degree of Magiter Pendidikan (M.Pd.) in Ganesha University of Education in 2008. He started his career as an English lecturer in Bali State Polytechnic in 2009.

His research interests are both in English education and English literature, including designing learning model, designing engineering dictionary, and pragmatics. 